\title{
Isolation of bioactive compounds from Bergenia ciliata (haw.) Sternb rhizome and their antioxidant and anticholinesterase activities
}

\author{
Roheena Zafar², Habib Ullah', Muhammad Zahoor ${ }^{1 *}$ (1) and Abdul Sadiq ${ }^{3}$
}

\begin{abstract}
Background: Bergenia ciliata is a medicinal plant used for the treatment of diarrhea, vomiting, fever, cough, diabetes, cancer, pulmonary disorders and wound healing.

Methods: In this study, Bergenia ciliata crude extract, subfractions, and isolated compounds were evaluated for their antioxidant and anticholinesterase potential. The free radical scavenging capacities of the extracts determined using DPPH and ABTS assays. The anticholinesterase potentials were determined using acetylcholine esterase and butyryl choline esterase enzymes. To determine the phytochemical composition, the extracts were subjected to HPLC analysis and silica gel column isolation. Based on HPLC fingerprinting results, the ethyl acetate fraction was found to have more bioactive compounds and was therefore subjected to silica gel column isolation. As a result, three compounds; pyrogallol, rutin, and morin were isolated in the pure state. The structures of the isolated compounds were elucidated using spectroscopic techniques like ${ }^{1} \mathrm{H}-\mathrm{NMR}$, IR and UV-Visible.

Results: The crude extract showed maximum anticholinesterase (acetylcholinesterase $=90.22 \pm 1.15 \%$ and butyrylcholinesterase $=88.22 \pm 0.71 \%)$ and free radical scavenging $(87.37 \pm 2.45$ and $83.50 \pm 0.70 \%$ respectively against DPPH and ABTS radicals) potentials. The total phenolic contents (expressed as equivalent of gallic acid; mgGAE/g) were higher in ethyl acetate fraction $(80.96 \pm 1.74)$ followed by crude extract $(70.65 \pm 0.86)$ while the flavonoid contents (expressed as quercetin equivalent; mgQE/g) and were higher in crude extract (88.40 \pm 1.12 ) followed by n-butanol fraction ( $60.10 \pm 1.86)$. The isolated bioactive compounds pyrogallol, rutin, and morin were found active against ABTS and DPPH free radicals. Amongst them, pyrogallol was more active against both free radicals. Reasonable anticholinesterase activities were recorded for pyrogallol against selected enzymes.
\end{abstract}

Conclusion: The extracts and isolated compounds showed antioxidant and acetylcholinesterase inhibitory potentials. It was concluded that this plant could be helpful in the treatment of oxidative stress and neurological disorders if used in the form of extracts.

Keywords: Bergenia ciliata rhizome, Total phenolic contents, Total flavonoid contents, Antioxidants, Anticholinesterase assay, Pyrogallol, Rutin, Morin

\footnotetext{
* Correspondence: mohammadzahoorus@yahoo.com

'Department of Chemistry, University of Malakand, Chakdara, Dir Lower, KPK

18800, Pakistan

Full list of author information is available at the end of the article
}

(c) The Author(s). 2019 Open Access This article is distributed under the terms of the Creative Commons Attribution 4.0 International License (http://creativecommons.org/licenses/by/4.0/) which permits unrestricted use, distribution, and reproduction in any medium, provided you give appropriate credit to the original author(s) and the source, provide a link to the Creative Commons license, and indicate if changes were made. The Creative Commons Public Domain Dedication waiver (http://creativecommons.org/publicdomain/zero/1.0/) applies to the data made available in this article, unless otherwise stated. 


\section{Background}

For thousands of years, plants have been used as sources of medicines by mankind. According to the World Health Organization, even today about $80 \%$ of the world population depends on traditional medication from plants as they are factories of natural phytochemicals [1]. Phenolic compounds are an important group amongst the phytochemicals naturally prepared by plants [2]. Most of the phenolic compounds have antioxidant properties and help in the prevention of heart diseases, reduction of inflammation, lowering the incidence of diabetes, cancers and mutagenesis in human [3]. The interest in the isolation of antioxidant from medicinal plants has been increased many folds from the last two decades as they have minimum incidences of side effects and are widely used in scientific research and industries [4]. A number of free radicals are constantly produced inside the human body during normal metabolic processes. About 1/4th of the oxygen inhaled is converted into free radicals. They are very reactive and causes a number of health complications. Antioxidants have the potential to scavenge them and maintain health [5-7].

A number of synthetic antioxidants like butyl hydroxyanisole and butyl hydroxytoluene have been used in food products as preservatives. However, the toxicological studies on butyl hydroxyanisole and butyl hydroxytoluene have shown that they can induce impairment of blood clotting in the experimental animal. The butyl hydroxytoluene has toxic effects on the lungs as well. Butylhydroxyanisole can induce tumor in the forestomach of experimental animals whereas long term exposure to butylhydroxytoluene can induce liver tumor in them [8]. Due to the side effects of synthetic antioxidants, the use naturally occurring antioxidants in pharmaceutical products, foods, and cosmetics industries have been increased [9-11]. Studies in this regards are needed to determine the antioxidant power of naturally occurring compounds and to develop efficient methods for their extraction, and isolation.

A number of useful secondary metabolites like gallic acid, tannic acid, glucose, mucilage, bergenin, stigmasterol, $\beta$-sitosterol, arbutin, phytol, damascenone, 3methyl-2-buten-1-ol etc. have been isolated from Bergenia ciliata, Bergenia ligulatas and Bergenia stracheyi [12-14]. Various parts of these species are used to remove urinary bladder stone and have shown antilithics, diuretic, anti-bradykinin, antiviral, antipyretic, antibacterial, anti-inflammatory, hepatoprotective, insecticidal and $\alpha$-glycosidase activities [11]. Amongst the mentioned three species of genus Bergenia, Bergenia ciliata is widely used in folk medicines and have exhibited antitussive, antiulcer, antioxidant, antibacterial, hypoglycemic, toxicological anticancer and ant-adiabatic activities [12].

The high demand and importance of natural antioxidant from plants origin promoted us to evaluate the Bergenia ciliata rhizome anticholinesterase and antioxidant potentials. First the crude extract and sub fractions were screened for their antioxidant and cholinesterase inhibitory potentials. The extracts were then subjected to HPLC analysis for the identification of phenolic compounds present in them. Based on HPLC finger printing results ethyl acetate fraction was subjected to silica gel column isolation that led to isolation of three bioactive compounds: pyrogallol, rutin and morin. The isolated compounds were characterized by FTIR and NMR.

\section{Methods}

\section{Chemicals, drugs and standards}

The antioxidant standards: quercetin, morin, rutin, pyrogallol, mandalic acid, hydroxy benzoic acid, phloroglucinol and chlorogenic acid were obtained from Sigma-Aldrich France. From the same firm galanthamine (from Lycoris Sp.) was also obtained. Follin-ciocalteu reagent, sodium carbonate, 5, 5-dithio-bis-nitrobenzoic acid (DTNB) and 2,2-Diphenyle-1 picrylhydrazyle (DPPH) were purchased from Sigma Aldrich CHEMIE GmbH USA. Aluminum chloride, sodium nitrite, sodium hydroxide, ethanol, methanol, ascorbic acid, 2,2'azino-bis-3 ethylbenzothiazoline-6-sulfonic acid (ABTS) were bought from sigma Aldrich Germany. Phosphate buffer ( $\mathrm{pH} 8$ ), butyryl thiocholine iodide, acetylthiocholine iodide, acetyl cholinesterase from Electric eel (type-VI-S) and butyryl cholinesterase from equine used in enzyme inhibition assays were obtained from Sigma-Aldrich USA. All the chemicals used were of analytical grade except the HPLC solvents which were HPLC grade and were purchased from DaeJung Korea. They were used as such without any further purification. Distilled water used for HPLC analysis and antioxidant assays were prepared in biochemistry lab using automatic water still (Daihen labtech, china). The HPLC solvents were subjected to sonication (Elmasonic, Model E 30 $\mathrm{H})$ to remove air bubbles before use.

\section{Plant sample collection}

The rhizomes of the Bergenia ciliata (Fig. 1) were collected from Laram Mountain, Dir Lower, KPK province of Pakistan in January 2015. The plant was authenticated by Dr. Nisar Department of Botany University of Malakand. A voucher specimen (1019HU) was also deposited in the Herbarium of Malakand University.

\section{Extraction and fractionation}

About $5 \mathrm{~kg}$ of fresh rhizomes of the B. ciliata were thoroughly washed with tap water to remove dust and soil particles and were kept in a shady place at room temperature for 4 weeks. The dried sample mass obtained after drying was $2.05 \mathrm{~kg}$ which was then grinded into fine powder. To obtain crude extract, the powder sample was soaked in $90 \%$ methanol $(8 \mathrm{~L})$ for $72 \mathrm{~h}$. The mixture was then filtered using Whattman filter paper. 


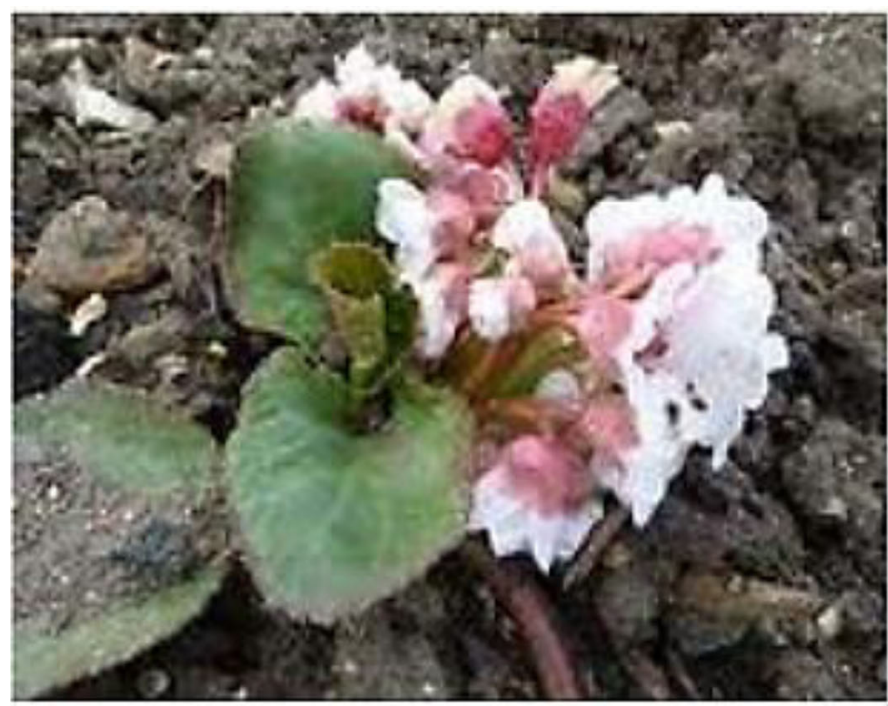

a

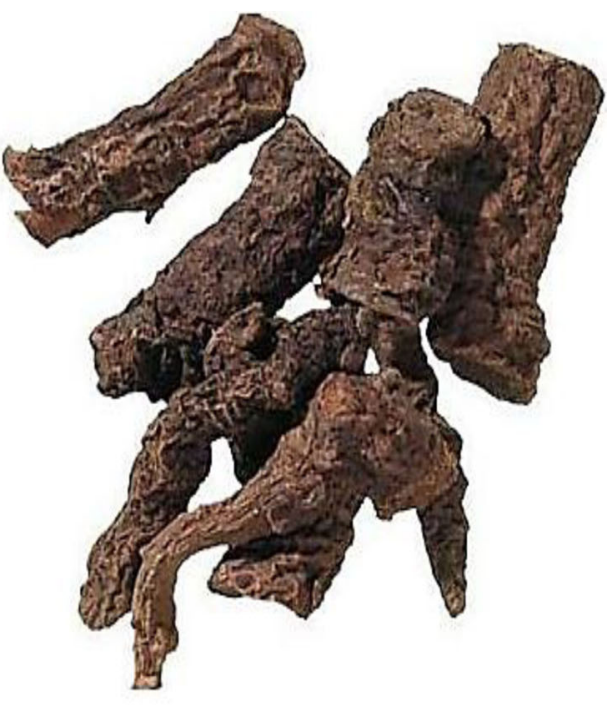

b

Fig. 1 Bergenia ciliata $a=$ whole plant, $b=$ part of the plant used in this study (rhizome)

The residue left was dipped again in methanol for $72 \mathrm{~h}$ and the filtrates from this step were then combined with the previous one. The filtrates were evaporated in rotary evaporator (Rota vapor R-200 Buchi, Switzerland) at $45^{\circ} \mathrm{C}$ under reduced pressure. The semisolid mass obtained was then kept in open atmosphere to evaporate the remaining solvent. The final mass of crude solid extract was $380 \mathrm{~g}$. Fractionation of the crude extract was done according to the described protocol of Haq et al. [12]. Appropriate amount ( $350 \mathrm{~g})$ of crude extract was taken and dissolved it in $900 \mathrm{ml}$ of distilled water and subjected to solvent-solvent extraction. All extracts were analyzed through reverse phase HPLC for the identification of possible phenolic antioxidants. The ethyl acetate fraction was rich in bioactive compounds and was subjected to silica gel column isolation.

\section{Determination of total phenolic content}

The total phenolic content in Bergenia ciliata rhizome crude extract and sub fractions were determined using Follin-ciocalteu assay with a little modification [14]. For the preparation of extracts standard solutions, $5 \mathrm{mg}$ of each extract were dissolved in $5 \mathrm{ml}$ methanol. About 1 $\mathrm{ml}$ of Follin-ciocalteu reagent was taken and diluted to $10 \mathrm{ml}$ with distilled water. Working standards of each extract were prepared by mixing $1 \mathrm{ml}$ (each) standard solution with $9 \mathrm{ml}$ distilled water. To each test tube, 1 $\mathrm{ml}$ of diluted Follin-ciocalteu reagent was added and allowed to stand for $6 \mathrm{~min}$. To reaction mixtures in each test tube then $10 \mathrm{ml}$ of $7 \%$ sodium carbonate solution was added and diluted further to $25 \mathrm{ml}$ by the addition of distilled water and incubated for $90 \mathrm{~min}$ at room temperature. The absorbance of the samples were recorded at $760 \mathrm{~nm}$ using UV spectrophotometer. For the determination of total phenolic contents a calibration curve of gallic acid ( 0 to $100 \mathrm{mg} / \mathrm{ml}$ ) was drawn. The total phenolic contents were expressed as milligrams of gallic acid equivalent (mg GAE/g) per gram of dry sample.

\section{Determination of total flavonoid content}

For the determination of total flavonoid contents in Bergenia ciliata rhizome extracts, the procedure described by Park et al. was followed [15] with little modification. About $5 \mathrm{mg}$ of each of the extracts were dissolved in $5 \mathrm{ml}$ of methanol. From each of these standard solutions, $1 \mathrm{ml}$ were mixed with $9 \mathrm{ml}$ distilled water and finally with $1 \mathrm{ml} \mathrm{NaNO} 2$ (5\%). The mixtures were allowed to stand for $6 \mathrm{~min}$ to proceed the reaction. Then $2 \mathrm{ml}$ of $10 \%$ aluminum chloride solution was added to each and allowed to stand for $5 \mathrm{~min}$. Then 2 $\mathrm{ml}$ sodium hydroxide $(1 \mathrm{M})$ was added sequentially to the mixtures. Finally, the absorbance of the mixture at $510 \mathrm{~nm}$ was recorded using UV spectrophotometer. For the determination of total flavonoids content standard quercetin curve $(0$ to $200 \mathrm{mg} / \mathrm{ml})$ was drawn. The total Flavonoid contents were expressed as quercetin equivalent in $\mathrm{mg}$. $\mathrm{QE} /$ $\mathrm{g}$ of the dry sample.

\section{Determination of free radical scavenging activities using DPPH assay}

The free radical scavenging abilities of the extracts were determined using 2,2- Diphenyl-1-picrylhydrazyl (DPPH) assay modified by Brand-Williams et al. with some modification [16]. In oxidized form of DPPH have deep violet color. On getting electrons from antioxidants the deep violet color changes to yellow color. DPPH solution was prepared by 
dissolving $20 \mathrm{mg}$ in $100 \mathrm{ml}$ methanol (stock solution). From this solution $3 \mathrm{ml}$ were taken and its absorbance was adjusted to 0.75 at $515 \mathrm{~nm}$ (control solution). For the formation of free radical, the stock DPPH solution was covered with aluminum foil and kept in dark place for $24 \mathrm{~h}$. For the preparation of stock solutions, $5 \mathrm{mg}$ of each extracts were dissolved in $5 \mathrm{ml}$ of methanol $(5000 \mu \mathrm{g} / 5 \mathrm{ml})$. Different dilution $(1000,500,250,125$ and $62.5 \mu \mathrm{g} / \mathrm{ml})$ were prepared from stock solutions through serial dilution. About $2 \mathrm{ml}$ from each dilution were mixed with $2 \mathrm{ml}$ of DPPH solution and incubated for $15 \mathrm{~min}$ in darkness. The percentage inhibition of DPPH free radical by extracts was calculated using the following formula:

$$
\text { \%inhibition }=\frac{A-B}{A} X 100
$$

Where A is the absorbance of DPPH in oxidized state and $B$ is the absorbance of mixture after 15 min of reaction. Ascorbic acid was used as standard antioxidant.

\section{ABTS free radical scavenging assay}

The 2, 2-azinobis (3-ethylbenzthiazoline)-6-sulfonic acid (ABTS) free radicals scavenging assay was used to determine the antioxidant potential of the Bergenia ciliata rhizome extracts, following the standard procedure devised by Re et al. [17]. ABTS (7 mM) and potassium per sulphate $(2.45 \mathrm{mM})$ solutions were prepared in $100 \mathrm{~mL}$ methanol. These two solutions were mixed thoroughly and kept in dark overnight for the formation of free radical. About $3 \mathrm{ml}$ were taken from this stock solution and its absorbance was adjusted to 0.76 at $745 \mathrm{~nm}$ (control solution). About $300 \mu \mathrm{l}$ of test samples were mixed with $3 \mathrm{ml}$ of ABTS solution and incubated for $15 \mathrm{~min}$ at $25^{\circ} \mathrm{C}$. The absorbance of the mixture was measured using a double beam spectrophotometer at $745 \mathrm{~nm}$. The same procedure was followed for the preparation of different dilution of ascorbic acid (positive control). The data was recorded in triplicate and percent ABTS free radicals scavenging activities were calculated using Eq. 1.

\section{Anticholinesterase assays}

Acetyl cholinesterase (AChE) and butyryl cholinesterase (BChE) were used to evaluate the enzyme inhibitory potential of Bergenia ciliata rhizome extracts and isolated compounds using Ellman's assay [18]. The mentioned enzymes when act on their respective substrates acetylthiocholine iodide and butyrylthiocholine iodide hydrolyze them which then on complexation with 5-thio-2-nitrobenzoate anion formed from DTNB give yellow color. The color change is recorded after $15 \mathrm{~min}$ by spectrophotometer. Phosphate buffer $(\mathrm{pH}=8)$ was prepared by mixing $1.36 \mathrm{~g} / 100 \mathrm{~mL}$, potassium dihydrogen phosphate and $1.74 \mathrm{~g} / 100 \mathrm{~mL}$ dipotassium hydrogen phosphate (6 and 94\% respectively).
The AChE solution was prepared by dissolving $0.5 \mathrm{mg}$ of enzyme in $0.5 \mathrm{ml}$ of phosphate buffer to get 1000 unit $/ \mathrm{ml}$ and $\mathrm{BChE}$ solution was also prepared by dissolving $1 \mathrm{mg}$ in $1 \mathrm{ml}$ of phosphate buffer to get $10 \mathrm{unit} / \mathrm{ml}$. These two solutions were further diluted by phosphate buffer till a final concentration of $0.03 \mathrm{unit} / \mathrm{ml}$ and $0.1 \mathrm{unit} / \mathrm{ml}$ respectively. DTNB solution $(0.0002 \mathrm{M})$ and ATChI and BTChI $(0.0005$ $\mathrm{M})$ were prepared and kept in reagent bottles in refrigerator before use.

\section{Spectroscopic analysis}

For spectroscopic determination of the mentioned enzyme inhibition, $1 \mathrm{ml}$ of crude extract and sub fractions were taken from dilutions $(125-1000 \mu \mathrm{g} / \mathrm{ml})$ in test tubes. To each test tube, $100 \mu \mathrm{l}$ of enzyme and DTNB solutions were added and incubated for $15 \mathrm{~min}$ at $25^{\circ} \mathrm{C}$. After this $100 \mu \mathrm{l}$ substrates (AChEI, BChEI) were added to each test tube and allowed to stand for $15 \mathrm{~min}$. The absorbance of mixtures were recorded at $412 \mathrm{~nm}$. A negative control was prepared by mixing all the above mention components except plant extracts. Galanthamine was used as a positive control. The same procedure was used for the preparation of Galanthamine (standard) solutions as well. For each sample absorption was recorded for 4 minutes. Percent activities of enzyme and percent inhibition were calculated using following relations.

$$
\begin{aligned}
& V=\frac{\Delta A b s}{\Delta T} \\
& \text { \%enzyme activity }=\frac{V}{\operatorname{Vmax}} \times 100
\end{aligned}
$$

Where $\mathrm{V}$ is the rate of reaction in the presence of inhibitor and $\mathrm{V}_{\max }$ is the rate of reaction without inhibitor.

\section{Determination of phenolic contents through HPLC Preparation of sample and standards}

For the identification of phenolic compound in Bergenia ciliata rhizome the previously reported method devised by Zeb was used [19]. About $1 \mathrm{~g}$ of powder plant sample was mixed with $10 \mathrm{ml}$ methanol and water $(1: 1 ; 10 \mathrm{ml} ; \mathrm{v} / \mathrm{v}) \mathrm{mix}-$ ture and vortexed for $15 \mathrm{~min}$. The mixture was shaken for 1 $\mathrm{h}$ and then filtered with Whattman filter (pore size of $0.7 \mu \mathrm{m}$ ). The mixture was then centrifuged at $4000 \mathrm{rpm}$ for $15 \mathrm{~min}$. The supernatant were filtered again through PTFE Agilent (pore size $0.45 \mu \mathrm{m}$ ). The filtrate were collected into $2 \mathrm{ml} \mathrm{HPLC}$ vials and were labeled with proper code and place in refrigerator till further use. Standard solutions of quercetin, morin, rutin, mandalic acid, pyrogallol, hydroxy benzoic acid, phloroglucinol and chlorogenic acid having concentrations $90 \mathrm{ng}$ each were prepared in methanol. 


\section{HPLC-UV conditions}

The HPLC system used was an Agilent 1260 having basic parts like quaternary pump, auto sampler, degasser and ultra violet (UV) detector. The separation was achieved via Agilent Zorbax Eclipse C18 column $(4.6 * 200 \mathrm{~mm}, 5 \mu \mathrm{m})$. The gradient system consisting of solvent A (methanol, acetic acid, deionized water, 10:2:88, v/v and solvent B (methanol, acetic acid, deionized water, 90:2:8, v/v). With $100 \% \mathrm{~A}$, the efficient gradient program was started at $0 \mathrm{~min}, 85 \% \mathrm{~A}$ at 5 $\mathrm{min}, 50 \% \mathrm{~A}$ at $20 \mathrm{~min}, 30 \% \mathrm{~A}$ at $25 \mathrm{~min}$, and $100 \% \mathrm{~B}$ from 30 to $40 \mathrm{~min}$. The flow rate of sample was $1 \mathrm{ml} / \mathrm{min}$. The identification of phenolic compounds were done by comparing the retention times of particular component in sample chromatogram with that of the available standards (chromatogram), while from $\%$ peaks area; quantification of the identified compounds were made.

\section{Isolation of phenolic compounds through column chromatography}

The HPLC Chromatograms of sub fractions were compared for presence of bioactive compounds. Amongst them the ethyl acetate fraction was rich in phenolic compounds and was subjected to silica gel column isolation. Silica gel was used as adsorbent in the large and pencil column for the separation of active components. For packing of column the silica gel was suspended in required solvent for $3 \mathrm{~h}$ to swell and after this it was introduced into the column with care. Little amount of the ethyl acetate fraction was dissolved in a suitable solvent and was mixed with silica gel to form slurry. After mixing well the slurry was allowed to dry for $48 \mathrm{~h}$. The dried slurry was then grinded to fine powder and loaded to column in such a way that the top of the column was not disturbed. The column was eluted with suitable solvent system comprising of the ethyl acetate and n-hexane mixed in different proportions. The solvent flow was controlled by peristaltic pump (SEKO Italy) to facilitate the elution. The elution was started from $n$-hexane followed by increase in polarity of $n$-Hexane/ethyl acetate gradients up to $50 \%$ ethyl acetate/n-hexane (1:1) gradient that afforded 20 sub-fractions $\left(\mathrm{C}_{1}-\mathrm{C}_{20}\right)$. Based on TLC results, fractions were combined according to their separation profile. All these sub fractions were then re- chromatogram using pencil column. The isolated compounds were then subjected to HPLC, FTIR and NMR analysis for purity and structural elucidation.

\section{Statistical analysis}

Each experiment was performed in triplicates and values were expressed as mean \pm SEM. Two- way ANOVA followed by multiple comparison Bonferroni's test was applied for the comparison of positive control with the test groups. The $P$ values less than or equal to 0.05 were considered as statistically significant. $\mathrm{IC}_{50}$ values were calculated by linear regression analysis among the percent inhibition against the extracts and isolated compound concentrations via Excel program. Regression (y) and linear correlation $\left(R^{2}\right)$ for phenolic and flavonoids contents and various biological activities such as anticholinesterase and antioxidants were determined using Microsoft Excel 2007.

\section{Results and discussion}

Total phenolic and flavonoid contents

The phenolic and flavonoid contents in crude extract and sub fractions of Bergenia ciliata rhizome are presented in Table 1. The highest phenolic contents were recorded for ethyl acetate fraction $(80.96 \pm 1.74)$ follow by $n$-butanol $(63.49 \pm 2.04)$, crude $(70.65 \pm 0.86)$, chloroform $(53.59 \pm 0.80)$, aqueous $(42.83 \pm 1.43)$, and $n$ hexane $(23.00 \pm 1.21)$ extracts. The phenolic contents were expressed as Gallic acid equivalent (mgGAE/g of dry sample). The total flavonoid contents (Table 1) were highest in crude extract $(88.40 \pm 1.12)$ followed by sub fractions in the following order; n-butanol fraction $(72.70 \pm$ $0.87)>$ chloroform $(60.10 \pm 1.86)>$ aqueous $(39.84 \pm 1.12)>$ ethyl acetate $(26.30 \pm 1.08)>$ n-hexane $(12.94 \pm 1.18)$. They were expressed as quercetin equivalent $(\mathrm{mg} \mathrm{QE} / \mathrm{g}$ of dry sample).

\section{DPPH/ABTS radical scavenging activities}

The antioxidant potential of Crude extract and subfractions of the rhizome of Bergenia ciliata were studied using DPPH and ABTS assays. The percent free radical scavenging potential the crude extract was higher $\left(\mathrm{IC}_{50}\right.$ $-=2 \mu \mathrm{g} / \mathrm{ml}$ ) than the sub fractions. Amongst the

Table 1 Total phenolic and Flavonoid content in Bergenia ciliata rhizome crude extract and their different subtractions

\begin{tabular}{llll}
\hline Samples & Total phenolic (mg GAE/g) of dry sample) & Sample & Total flavonoid (mg qe/g) of dry sample \\
\hline Ethyl acetate & $80.96 \pm 1.74$ & crude & $88.40 \pm 1.12$ \\
Crude & $70.65 \pm 0.86$ & n-butanol & $72.70 \pm 0.87$ \\
n-butanol & $63.49 \pm 2.04$ & Chloroform & $60.10 \pm 1.86$ \\
Chloroform & $53.59 \pm 0.80$ & aqueous & $39.84 \pm 1.12$ \\
Aqueous & $42.83 \pm 1.43$ & Ethyl acetate & $26.30 \pm 1.08$ \\
n-hexane & $23.00 \pm 1.21$ & n-hexane & $12.94 \pm 1.18$ \\
\hline
\end{tabular}

GAE Gallic acid equivalent, QE Quercetin equivalent each value in the table is represented as mean $\pm \operatorname{SEM}(n=3)$ 
fractions n-butanol was most potent with $\mathrm{IC}_{50}$ value of $122 \mu \mathrm{g} / \mathrm{ml}$. The $\mathrm{IC}_{50}$ values of other fractions; ethyl acetate, chloroform, aqueous and n-hexane were 170, 205, 440 , and $830 \mu \mathrm{g} / \mathrm{ml}$ respectively (Table 2 and Fig. 2a). Ascorbic acid was used as a standard and its $\mathrm{IC}_{50}$ value was $50 \mu \mathrm{g} / \mathrm{ml}$.
Against ABTS free radical again Crude extract was more potent with $\mathrm{IC}_{50}=70 \mu \mathrm{g} / \mathrm{ml}$ (Table 2 and Fig. 2b). Amongst sub fractions, n-butanol fraction showed promising antioxidant activity with $\mathrm{IC}_{50}=140 \mu \mathrm{g} / \mathrm{ml}$, followed by ethyl acetate, chloroform, aqueous and $\mathrm{n}$ - hexane with $1 \mathrm{C}_{50}$ of $186,267,650$ and $910 \mu \mathrm{g} / \mathrm{ml}$ respectively.

Table 2 Percent DPPH and ABTS radical scavenging potential of crude extract and their sub fractions of Bergenia ciliata rhizome using ascorbic acid as standard

\begin{tabular}{|c|c|c|c|c|c|}
\hline Samples & $\begin{array}{l}\text { Concentrations }(\mu \mathrm{g} / \\
\mathrm{mL})\end{array}$ & $\begin{array}{l}\text { DPPH Percent inhibition (mean } \pm \\
\text { S.E.M) }\end{array}$ & $\begin{array}{l}\mathrm{DPPH} I \mathrm{C}_{50}(\mu \mathrm{g} / \\
\mathrm{mL})\end{array}$ & $\begin{array}{l}\text { ABTS percent inhibition (mean } \pm \\
\text { S.E.M) }\end{array}$ & $\begin{array}{l}\text { ABTS IC }{ }_{50}(\mu \mathrm{g} / \\
\mathrm{mL})\end{array}$ \\
\hline \multirow[t]{5}{*}{ Crude } & 1000 & $87.50 \pm 0.70^{*}$ & & $85.37 \pm 2.45^{\mathrm{ns}}$ & \\
\hline & 500 & $77.66 \pm 1.20^{\mathrm{ns}}$ & & $76.33 \pm 0.67^{\mathrm{ns}}$ & \\
\hline & 250 & $70.31 \pm 0.76^{n s}$ & 62 & $69.00 \pm 1.00 \mathrm{~ns}$ & 70 \\
\hline & 125 & $62.34 \pm 2.45^{\mathrm{ns}}$ & & $57.33 \pm 0.66^{\mathrm{ns}}$ & \\
\hline & 62.5 & $50.50 \pm 0.70^{\mathrm{ns}}$ & & $48.45 \pm 0.52^{\mathrm{ns}}$ & \\
\hline \multirow[t]{5}{*}{ n-butanol } & 1000 & $82.62 \pm 0.76^{* * *}$ & & $80.26 \pm 1.03^{* * *}$ & \\
\hline & 500 & $74.32 \pm 0.62^{* *}$ & & $70.05 \pm 0.77^{* * *}$ & \\
\hline & 250 & $63.00 \pm 1.73^{* * *}$ & 122 & $60.30 \pm 2.33^{* * *}$ & 140 \\
\hline & 125 & $47.22 \pm 0.66^{* * *}$ & & $44.97 \pm 1.09^{* * *}$ & \\
\hline & 62.5 & $39.03 \pm 0.60^{* * *}$ & & $34.10 \pm 0.50^{* * *}$ & \\
\hline \multirow{5}{*}{$\begin{array}{l}\text { Ethyl } \\
\text { acetate }\end{array}$} & 1000 & $77.66 \pm 2.45^{* * *}$ & & $75.00 \pm 0.88^{* * *}$ & \\
\hline & 500 & $66.07 \pm 0.56^{* * *}$ & & $65.66 \pm 0.81^{* * *}$ & \\
\hline & 250 & $59.33 \pm 1.46^{* * *}$ & 170 & $57.02 \pm 0.44^{* * *}$ & 186 \\
\hline & 125 & $44.08 \pm 0.73^{* * *}$ & & $42.11 \pm 0.66^{* * *}$ & \\
\hline & 62.5 & $32.50 \pm 3.45^{* * *}$ & & $27.64 \pm 2.39^{* * *}$ & \\
\hline \multirow[t]{5}{*}{ Chloroform } & 1000 & $70.27 \pm 0.71^{* * *}$ & & $68.84 \pm 0.47^{* * *}$ & \\
\hline & 500 & $61.31 \pm 0.60^{* * *}$ & & $57.33 \pm 0.78^{* * *}$ & \\
\hline & 250 & $53.33 \pm 1.45^{* * *}$ & 205 & $50.22 \pm 0.46^{* * *}$ & 267 \\
\hline & 125 & $40.05 \pm 0.56^{* * *}$ & & $35.01 \pm 0.52^{* * *}$ & \\
\hline & 62.5 & $27.12 \pm 0.66^{* * *}$ & & $23.25 \pm 0.38^{* * *}$ & \\
\hline \multirow[t]{5}{*}{ Aqueous } & 1000 & $62.18 \pm 0.67^{* * *}$ & & $60.15 \pm 0.44^{* * *}$ & \\
\hline & 500 & $51.50 \pm 0.55^{* * *}$ & & $48.33 \pm 1.33^{* * *}$ & \\
\hline & 250 & $42.02 \pm 0.57^{* * *}$ & 440 & $37.64 \pm 0.58^{* * *}$ & 600 \\
\hline & 125 & $28.37 \pm 0.65^{* * *}$ & & $24.62 \pm 0.85^{* * *}$ & \\
\hline & 62.5 & $16.56 \pm 2.38^{* * *}$ & & $13.03 \pm 0.86^{* * *}$ & \\
\hline \multirow[t]{5}{*}{ n-hexane } & 1000 & $54.27 \pm 0.72^{* * *}$ & & $52.50 \pm 0.50 * * *$ & \\
\hline & 500 & $42.49 \pm 0.50^{* * *}$ & & $40.00 \pm 1.08^{* * *}$ & \\
\hline & 250 & $34.07 \pm 0.58^{* * *}$ & 830 & $31.16 \pm 0.70^{* * *}$ & 910 \\
\hline & 125 & $25.31 \pm 0.67^{* * *}$ & & $22.06 \pm 2.38^{* * *}$ & \\
\hline & 62.5 & $12.66 \pm 1.45^{* * *}$ & & $10.04 \pm 1.54^{* * *}$ & \\
\hline \multirow{5}{*}{$\begin{array}{l}\text { Ascorbic } \\
\text { acid }\end{array}$} & 1000 & $92.94 \pm 0.86$ & & $89.67 \pm 0.73$ & \\
\hline & 500 & $80.29 \pm 0.79$ & 50 & $80.45 \pm 0.96$ & 64 \\
\hline & 250 & $71.93 \pm 0.45$ & & $68.34 \pm 2.16$ & \\
\hline & 125 & $62.90 \pm 0.48$ & & $58.90 \pm 0.85$ & \\
\hline & 62.5 & $52.88 \pm 0.32$ & & $49.78 \pm 0.76$ & \\
\hline
\end{tabular}




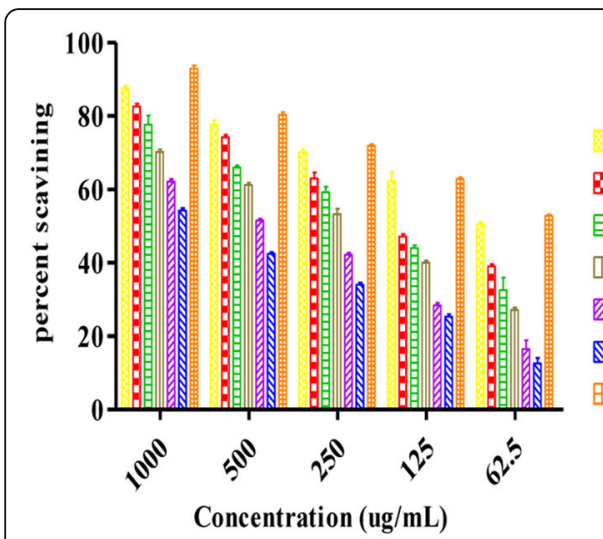

A

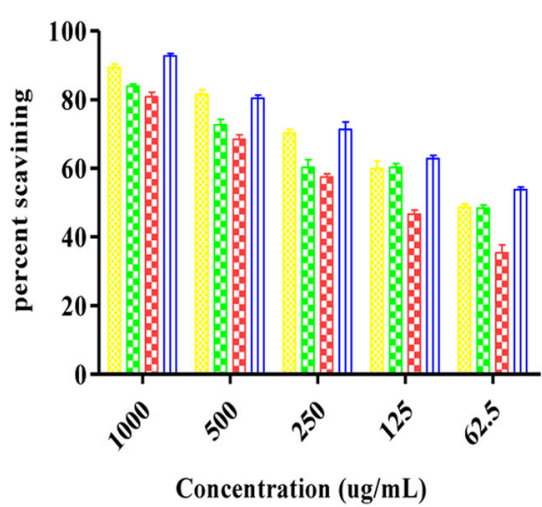

$\mathrm{C}$

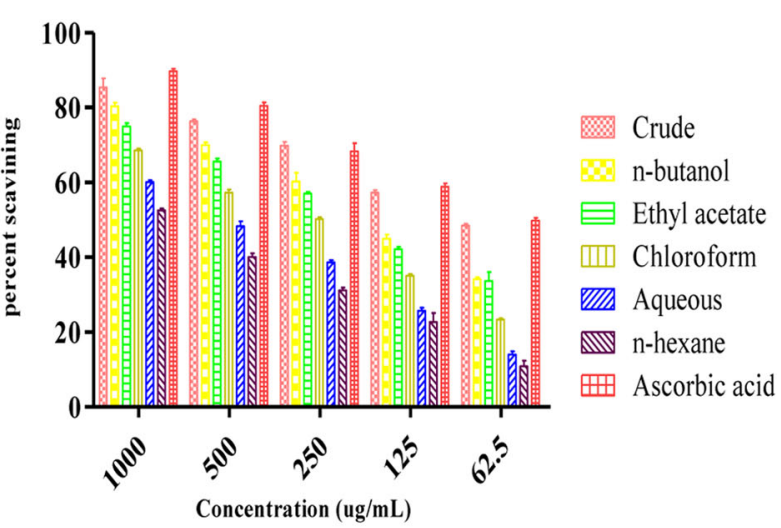

B

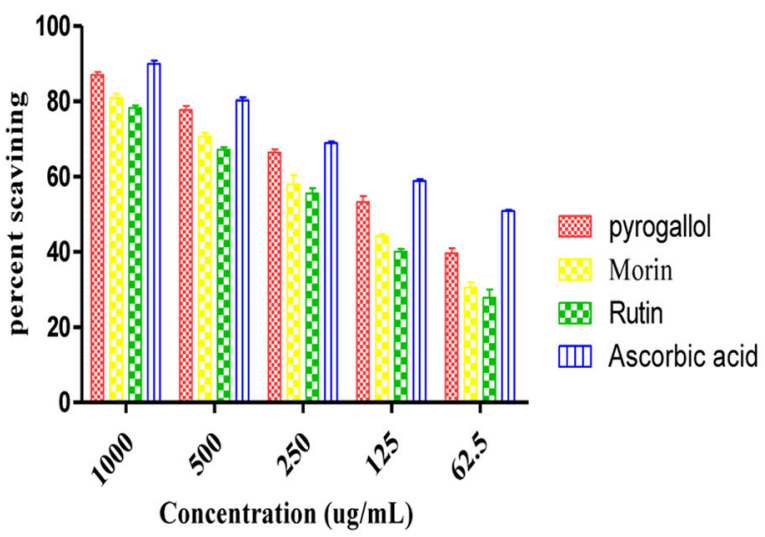

$\mathrm{D}$

Fig. $2 \% D P P H / A B T S$ free radical scavenging potential of $B$. ciliata rhizome extracts and isolated compounds ( $A=D P P H$ scavenging potentials of extracts. $B=$ ABTS scavenging potentials of extracts. $C=$ DPPH scavenging potentials of isolated compounds, $C=A B T S$ scavenging potentials of isolated compounds)

The already phytochemical screening reports on Bergenia ciliata revealed that it contains a number of phytoconstituent like flavonoid, steroids, terpenoids, tannin, saponins, anthraquinones and glycoside responsible for their antioxidant potentials $[20,21]$.

\section{Acetyl cholinesterase inhibition assays}

The cholinesterases; $\mathrm{AChE}$ and $\mathrm{BChE}$ are the key enzymes in the breakdown of acetylcholine and butyrylcholine. In some pathological conditions (neurological disorders like taxia, dementia, Alzheimer disease) there is need to inhibit these enzymes. The decreased level of acetylcholine within the nervous system of the body may be due to reduced acetyl-transferase or increased level of AChE. The hydrolysis of acetylcholine can be minimized by inhibiting $\mathrm{AChE}$ in the brain. A number of plants have been tested to enhance and alleviate the cognitive function and symptoms associated with Alzheimer disease [22]. The AChE and $\mathrm{BChE}$ percent inhibition and their $1 \mathrm{C}_{50}$ values extracts are given in Table 3 . The crude extract and sub fraction showed promising inhibition of acetyl cholinesterases. The highest percent inhibition of AChE was recorded for crude extract $(90.22 \pm 1.15,80.15 \pm 0.70$, $71.02 \pm 0.73,57.26 \pm 0.42$ respectively for the studied concentrations: $1000,500,250$, and $125 \mu \mathrm{g} / \mathrm{ml})$ with $\mathrm{IC}_{50}=$ $72 \mu \mathrm{g} / \mathrm{ml}$. Amongst the fractions, n-butanol fraction showed high percent inhibition $(82.33 \pm 1.07,70.23 \pm 3.31$, $58.07 \pm 1.20$ and $49.03 \pm 0.75$ for the afore mentioned concentrations) with $\mathrm{IC}_{50}$ value of $140 \mu \mathrm{g} / \mathrm{ml}$ followed by ethyl acetate fraction. All fractions showed concentration dependent activities. The $\mathrm{IC}_{50}$ calculated for chloroform, aqueous and n-hexane were: 311, 400, and $560 \mu \mathrm{g} / \mathrm{ml}$ respectively.

Against $\mathrm{BChE}$ the crude extract again showed highest potential with activities: $88.22 \pm 0.71, \quad 80.47 \pm 0.86$, $67.10 \pm 3.30$, and $56.75 \pm 2.25$ at studied concentrations of 1000, 500, 250 and $125 \mu \mathrm{g} / \mathrm{ml} \quad\left(\mathrm{IC}_{50}=80 \mu \mathrm{g} / \mathrm{ml}\right)$. Amongst the sub fractions $\mathrm{n}$-butanol fraction was more potent with activities of $80.00 \pm 1.5,71.80 \pm 0.90,61.12 \pm$ 0.65 , and $48.80 \pm 80$ at studied concentrations with $\mathrm{IC}_{50}$ 
Table 3 Percent AChE and BChE inhibition potentials of Bergenia ciliata Rhizome Crude extract and their sub fractions

\begin{tabular}{|c|c|c|c|c|c|}
\hline Sample & Concentration $(\mu \mathrm{g} / \mathrm{ml})$ & Percent AChE (mean \pm SEM) & AChE $I C_{50}(\mu \mathrm{g} / \mathrm{ml})$ & Percent BChE (mean \pm SEM) & $B C h E I C_{50}(\mu \mathrm{g} / \mathrm{ml})$ \\
\hline \multirow[t]{4}{*}{ Crude } & 1000 & $90.22 \pm 1.15^{\mathrm{ns}}$ & & $88.22 \pm 0.71^{* *}$ & \\
\hline & 500 & $80.15 \pm 0.70^{* *}$ & 72 & $80.47 \pm 0.86^{\mathrm{ns}}$ & 85 \\
\hline & 250 & $71.28 \pm 0.73^{\mathrm{ns}}$ & & $67.90 \pm 3.30^{* * *}$ & \\
\hline & 125 & $57.26 \pm 0.42^{* *}$ & & $56.75 \pm 2.25^{\mathrm{ns}}$ & \\
\hline \multirow[t]{4}{*}{ n-Butanol } & 1000 & $82.33 \pm 1.07^{* * *}$ & & $80.43 \pm 1.15^{* * *}$ & \\
\hline & 500 & $70.23 \pm 3.31^{* * *}$ & 140 & $71.80 \pm 0.90^{* * *}$ & \\
\hline & 250 & $58.67 \pm 1.20^{* * *}$ & & $61.20 \pm 0.65^{* * *}$ & 150 \\
\hline & 125 & $49.93 \pm 0.75^{* * *}$ & & $48.83 \pm 2.33^{* * *}$ & \\
\hline \multirow[t]{4}{*}{ Ethyl acetate } & 1000 & $75.32 \pm 2.45^{* * *}$ & & $73.26 \pm 0.60^{* * *}$ & \\
\hline & 500 & $66.34 \pm 0.60^{* * *}$ & & $60.31 \pm 0.81^{* * *}$ & \\
\hline & 250 & $53.66 \pm 1.17^{* * *}$ & 185 & $50.33 \pm 2.33^{* * *}$ & 215 \\
\hline & 125 & $44.76 \pm 0.73^{* * *}$ & & $35.85 \pm 0.68^{* * *}$ & \\
\hline \multirow[t]{4}{*}{ Chloroform } & 1000 & $66.69 \pm 0.45^{* * *}$ & & $69.19 \pm 0.72^{* * *}$ & \\
\hline & 500 & $57.39 \pm 3.26^{* * *}$ & & $60.66 \pm 0.94^{* * *}$ & \\
\hline & 250 & $46.19 \pm 1.08^{* * *}$ & 311 & $45.75 \pm 0.42^{* * *}$ & 350 \\
\hline & 125 & $36.80 \pm 0.73^{* * *}$ & & $34.69 \pm 0.49^{* * *}$ & \\
\hline \multirow[t]{4}{*}{ Aqueous } & 1000 & $60.45 \pm 2.33^{* * *}$ & & $65.37 \pm 0.50^{* * *}$ & \\
\hline & 500 & $55.63 \pm 1.40^{* * *}$ & & $51.27 \pm 0.81^{* * *}$ & \\
\hline & 250 & $43.11 \pm 0.78^{* * *}$ & 400 & $37.63 \pm 0.46^{* * *}$ & 470 \\
\hline & 125 & $31.66 \pm 0.76^{* * *}$ & & $24.31 \pm 2.42^{* * *}$ & \\
\hline \multirow[t]{4}{*}{ n-Hexane } & 1000 & $50.54 \pm 1.33^{* * *}$ & & $60.66 \pm 0.60^{* * *}$ & \\
\hline & 500 & $45.80 \pm 2.26^{* * *}$ & 650 & $47.56 \pm 0.60^{* * *}$ & \\
\hline & 250 & $30.38 \pm 0.47^{* * *}$ & & $33.46 \pm 0.88^{* * *}$ & 560 \\
\hline & 125 & $18.66 \pm 2.30^{* * *}$ & & $20.38 \pm 0.68^{* * *}$ & \\
\hline \multirow[t]{4}{*}{ Galanthamine } & 1000 & $95.32 \pm 0.88$ & & $94.50 \pm 0.71$ & \\
\hline & 500 & $87.74 \pm 0.55$ & 45 & $84.66 \pm 1.20$ & 60 \\
\hline & 250 & $76.44 \pm 0.60$ & & $76.72 \pm 0.72$ & \\
\hline & 125 & $64.58 \pm 0.54$ & & $60.83 \pm 0.69$ & \\
\hline
\end{tabular}

Galanthamine was used as a positive control. Data is represented as (mean \pm S.E.M) $n=3$. Values significantly different as compared to positive control, *: $P<0.05$, **: $P<0.01,{ }^{* * *}: P<0.001$, ns: $P>0.05$

value of $150 \mu \mathrm{g} / \mathrm{ml}$. The $\mathrm{IC}_{50}$ values of ethyl acetate, chloroform, n-hexane and aqueous fractions were; 350, 470 , and $560 \mu \mathrm{g} / \mathrm{ml}$ respectively (Table 3 ). The inhibition was dose dependent.

\section{Linear correlation of total phenolic and flavonoid} contents vs antioxidant and anticholinesterase activities A linear correlation of total phenolic and flavonoid content vs various biological activities such as antioxidant (DPPH, ABTS) and anticholinesterase (AChE, BChE) have been shown in Fig. 3. The regression value of $\% \mathrm{AChE}$ and \% BChE inhibition vs total phenolic contents (Fig. 3a and b) were 0.66 and 0.73 respectively while that of \% DPPH and ABTS scavenging vs TPC (Fig. $3 \mathrm{c}$ and d) were 0.98 and 0.85 respectively. The regression values of \% AChE and BChE VS TFC (Fig. 1e and $\mathrm{f}$ ) were 0.71 and 0.58 while that of $\% \mathrm{DPPH}$ and ABTS vs TFC (Fig. $3 g$ ) were 0.25 and 0.194 respectively. Comparatively, good correlations of the studied biological activities have been observed for TPC while that of TFC it was poor. It was concluded that the anticholinesterase and antioxidant capacities were due to phenolic constituents.

\section{Phenolic composition}

The phenolic compounds present in extracts were identified by comparing the HPLC chromatograms of samples with that of standards. The identification was based on comparison of retention times of the particular component with the available standards or by comparing with those reported in the literature. Those peaks were selected for quantification where the spectral purity was 

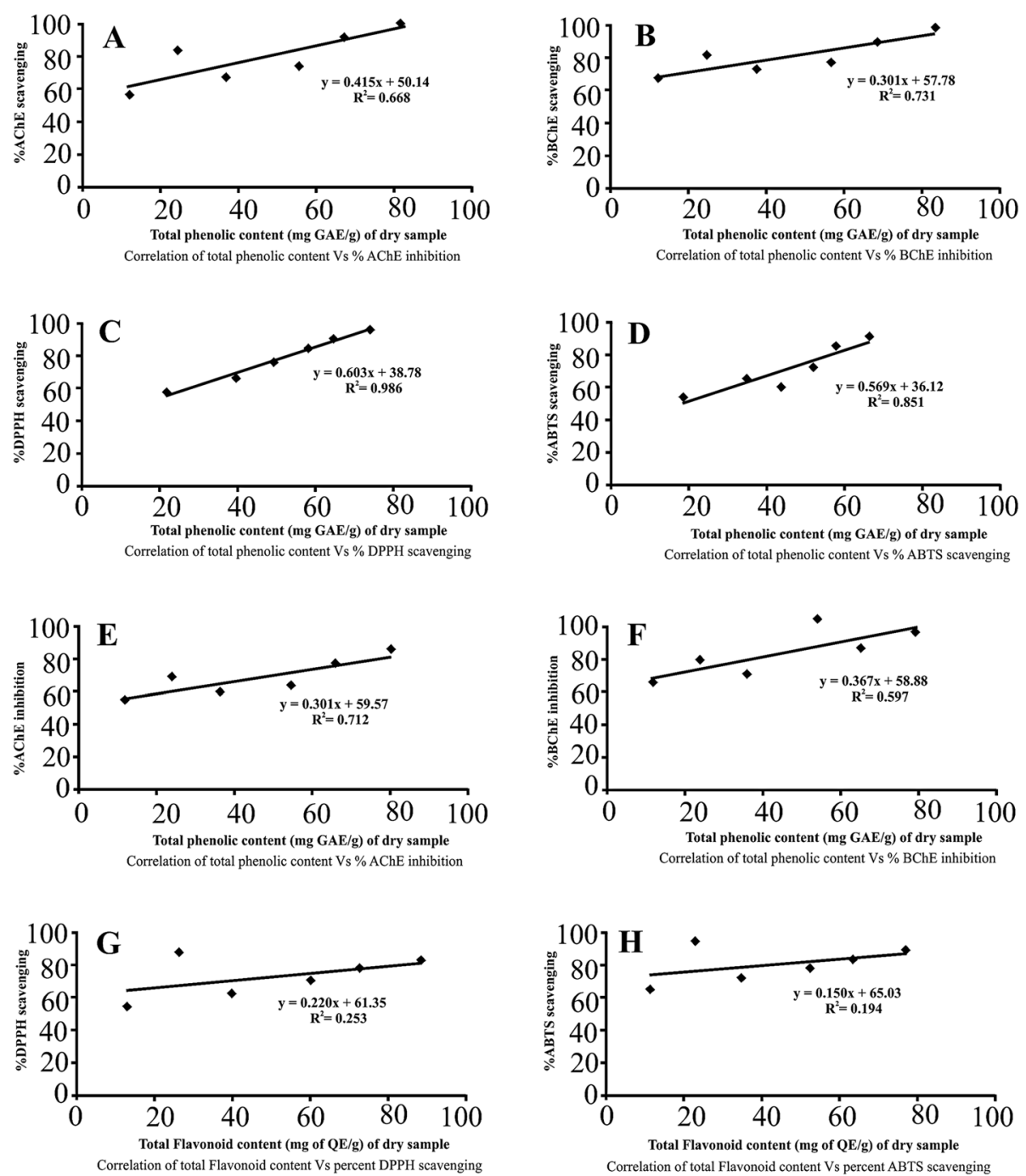

Fig. 3 Linear correlations for total Phenolics Vs AChE (a), BChE (b), DPPH (c), and ABTS (d) and for total Flavonoid content Vs AChE (e), BChE (f), $\mathrm{DPPH}(\mathbf{g})$, and ABTS $(\mathbf{h})$ activities

higher than $96 \%$. The quantification of the identified compounds were made by single point calibration method. Quercetin, morin, rutin, pyrogallol, hydroxy benzoic acid, phloroglucinol, mandalic acid, and chlorogenic acid were used as standard phenolic compounds (Additional file 1: Figure S1).

\section{Phenolic compounds in Bergenia ciliata}

HPLC chromatogram of Bergenia ciliata Rhizome extracts were obtained using Agilent 1260 system. The HPLC chromatograms of crude and ethyl acetate fractions are given in Additional file 1: Figures S2 and S3 while the detail identification of compounds is given in Table 4. In crude extract, compound 2, eluted at retention time $10.22 \mathrm{~min}$, was identified as quercetin $(0.46$ $\mathrm{mg} / 100 \mathrm{~g}$ ) and the compound $\mathbf{6}$, eluted at retention time $30.88 \mathrm{~min}$ was mandalic acid with a concentration of
$0.013 \mathrm{mg} / 100 \mathrm{~g}$. The quantification was done through the following formula:

$$
C x=\frac{A x * C s(\mathrm{mg} / \mathrm{ml}) * V(\mathrm{ml})}{\text { As*Sample }(\text { wt in } g)}
$$

Where

$C_{X}=$ Concentration of unknown

$\mathrm{A}_{\mathrm{S}}=$ Peak area of standard

$\mathrm{A}_{\mathrm{x}}=$ Peak area of unknown

$\mathrm{Cs}=$ Concentration of standard

The phenolic compounds identified in ethyl acetate fraction (Additional file 1: Figure S3) were given numbers 3, 4, 5, 7 and 8. Compound 3, eluted at retention time $12.76 \mathrm{~min}$, was morin with concentration $3.13 \mathrm{mg} /$ $100 \mathrm{~g}$. Compound 4 was identified as rutin which was 
Table 4 Identification and quantification of possible phenolic compounds in Bergenia ciliata rhizome crude extract and ethyl acetate fraction using reversed phase HPLC

\begin{tabular}{|c|c|c|c|c|}
\hline Peak & Retention time (min) & Possible identity & Quantity (mg per100g) of sample & Identification reference \\
\hline 2 & 10.22 & Quercetin & 0.46 & Standard \\
\hline 3 & 12.76 & Morin & 3.13 & Standard \\
\hline 4 & 22.67 & Rutin & 5.22 & Standard \\
\hline 5 & 28.67 & Pyrogallol & 2.53 & Standard \\
\hline 6 & 30.88 & Mandalic acid & 2.82 & Standard \\
\hline 7 & 35.49 & Phloroglucinol & 1.53 & Standard \\
\hline 8 & 36.31 & Hydroxy benzoic acid & 0.926 & Standard \\
\hline 9 & 4.5 & Gallic acid derivative & 0.88 & Fischer et al. [19] \\
\hline 10 & 13.9 & Quercetin-3- glucoside & 8.15 & Santos et al. [20] \\
\hline
\end{tabular}

eluted at retention time of $22.67 \mathrm{~min}$ (concentration $=$ $5.22 \mathrm{mg} / 100 \mathrm{~g})$. Compound 5 was identified as pyrogallol and was eluted at a retention time of $28.67 \mathrm{~min}$ (concentration $=2.53 \mathrm{mg} / 100 \mathrm{~g}$ ). Compounds 7 , and 8 eluted at retention times of 35.49 and 36.31 min were identified as phloroglucinol and hydroxy benzoic acid (concentrations 1.53 and $0.926 \mathrm{mg} / 100 \mathrm{~g}$ respectively). In n-butanol, $\mathrm{n}$ hexane, chloroform, and aqueous fractions the targeted compound peaks were absent however, some peaks of unknown compound were there which were not possible to identify from the standard chromatogram through retention time and spectra. Gallic acid derivative and quercetin-3-glucoside were identified in them by comparison of their retention with already reported work in literature [20, 21]. The molecular structures of identified compounds are given in Additional file 1: Figure S4.

\section{Isolation of phenolic compounds from Bergenia ciliata rhizome}

The silica gel column was eluted successively, using ethyl acetate and n-hexane solvent system with increasing polarities from 1 to $50 \%$. Different fractions were combined according to their TLC profile and visualized by UV light. Twenty sub fractions designated as $\mathrm{C}-1$ to C-20 were obtained which were re-subjected to silica gel column. The isolated and purified compounds were again subjected to HPLC analysis. A single broad peak confirms their purity and isolation. The three compounds were isolated and further characterized by FTIR and H-NMR. Their details are given below:

\section{Compound 5: pyrogallol (Benzene-1, 2, 3-triol)}

The compound 5, pyrogallol (Benzene-1, 2, 3-triol) was isolated from the ethyl acetate extract as white, lustrous crystals. Its molecular formula is $\mathrm{C}_{6} \mathrm{H}_{6} \mathrm{O}_{3}$ (Additional file 1: Figure S5), UV/Visible maximum absorption peak is at $275 \mathrm{~nm}$ and melting point is $133^{\circ} \mathrm{C}$. The HPLC chromatogram was developed to confirm their purity and isolation (Additional file 1: Figure S6). Its infrared (FTIR) absorption bands indicated the presence of hydroxyl group at $3537 \mathrm{~cm}^{-}$ 1 , the peak at $3050 \mathrm{~cm}^{-1}$ presents $\mathrm{C}-\mathrm{H}$, aromatic and $\mathrm{C}=\mathrm{C}$ bond stretching at $1622 \mathrm{~cm}^{-1}$ shows the presence of the aromatic nucleus (Additional file 1: Figure S7).

In ${ }^{1} \mathrm{H}-\mathrm{NMR}$ spectra, the triplets signal at $6.4 \mathrm{ppm}$ were assigned to proton at $\mathrm{C}-1$ and the duplets signal appeared at $6.2 \mathrm{ppm}$ were due to aromatic proton at C-2 respectively. In the same way the duplets signal was there at $4.8 \mathrm{ppm}$ for $\mathrm{C}-\mathrm{OH}$ (Additional file 1: Figure S8). The present data was in close agreement with the previously reported data [23].

\section{Compound 4: rutin (3, 3, 4, 5, 7-pentadroxyflavones-3- rutinoside)}

Compound 4, isolated as a light yellow powder from the ethyl acetate fraction was identified as rutin. Its molecular formula is $\mathrm{C}_{27} \mathrm{H}_{30} \mathrm{O}_{16}$ (Additional file 1: Figure S9), UV/ Vis range $=304 \mathrm{~nm}$ and Melting Point $=193^{\circ} \mathrm{C}$. The HPLC analysis showed pure and broad peak of rutin confirmed its isolation and purity (Additional file 1: Figure S10). The structure of compound $\mathbf{4}$ was elucidated with the help of FTIR and ${ }^{1} \mathrm{H}$-NMR and comparing its spectral and physical data with the already reported data. The IR spectrum showed absorption peaks for hydroxyl group at $3417 \mathrm{~cm}^{-1}$, the peak at $3050 \mathrm{~cm}^{-1}$ confirmed the aromatic $\mathrm{C}$-H group while peak at $1745 \mathrm{~cm}^{-1}$ was for the carbonyl functionality. The peak at $2935 \mathrm{~cm}^{-1}$ presenting the $\mathrm{C}-\mathrm{H}$ while $\mathrm{C}=\mathrm{C}$ double bond stretching at $1600 \mathrm{~cm}^{-1}$ indicating an aromatic nucleus (Additional file 1: Figure S11).

In the $\mathrm{H}^{1}$-NMR Spectrum the multiplet signal appeared in the range $3.72-3.35 \mathrm{ppm}$ were assigned to glucose protons and the duplets peak at 3.9, $1.6 \mathrm{ppm}$ indicate the saturated proton in glucose molecule. In the same way the glucose proton duplets peak appears at $4.3 \mathrm{ppm}$ of C-1. Similarly the duplet signals at $6.1,6.3$, 6.6 and $7.8 \mathrm{ppm}$ indicated the aromatic protons at C-6, 
C-8, C-5 and C-2 respectively (Additional file 1: Figure S12). The present data was in close agreement to the previously reported data [24].

\section{Compound 3: morin (2-(2, 4-Dihydroxyphenyl)-3, 5, 7- trihydroxychromen-4-one)}

Compound 3; morin was isolated from the ethyl acetate extract as yellow powder. Its molecular formula is $\mathrm{C}_{15} \mathrm{H}_{10} \mathrm{O}_{7}$ (Additional file 1: Figure S13), UV/Vis range $=263 \mathrm{~nm}$ and melting point $=299-300^{\circ} \mathrm{C}$. HPLC chromatogram of the isolated compound morin was also obtained which confirm its purity and isolation (Additional file 1: Figure S14). The FTIR absorption bands at $3430 \mathrm{~cm}^{-1}$ confirmed the presence of hydroxyl group and $\mathrm{C}=\mathrm{C}$ double bond stretching at $1653 \mathrm{~cm}^{-1}$ representing the aromatic nuclei. The peak at $2981 \mathrm{~cm}^{-1}$ shows the aromatic $\mathrm{C}-\mathrm{H}$ and the peak at $1739 \mathrm{~cm}^{-1}$ represent carbonyl functionality (Additional file 1: Figure S15).

The duplets signal at 6.21 and $6.46 \mathrm{ppm}$ in ${ }^{1} \mathrm{H}$ NMR spectra indicates the aromatic proton at C-6 and $\mathrm{C}-8$ respectively. While the signals at $7.53,6.70$, and $7.40 \mathrm{ppm}$ indicating the aromatic proton of ring
$\mathrm{B}$ at $\mathrm{C}-3, \mathrm{C}-5$ and $\mathrm{C}-6$ respectively. In the same way the duplets signal appeared at $4.78 \mathrm{ppm}$ was assigned to $\mathrm{C}-\mathrm{OH}$ at $\mathrm{C}-5, \mathrm{C}-7$ in the ring $\mathrm{A}$ as well as for $\mathrm{C}$ 2 and $\mathrm{C}-4$ in ring $\mathrm{B}$ respectively. The singlet signal at $12.86 \mathrm{ppm}$ presenting the $\mathrm{C}-\mathrm{OH}$ proton at $\mathrm{C}-3$ (Additional file 1: Figure S16). The present data was in close agreement with the reported research in literature [25].

\section{Antioxidant potential of isolated compounds}

The phenolic compounds; rutin, morin and pyrogallol isolated from the rhizome of Bergenia ciliata showed a high antioxidant potentials against DPPH and ABTS free radical when tested at different concentration ranging from 1000 to $62.5 \mu \mathrm{g} / \mathrm{ml}$. Against DPPH, the percent free radical scavenging potential were found higher for pyrogallol with $\mathrm{IC}_{50}$ value of $68 \mu \mathrm{g} / \mathrm{ml}$ followed by morin with $\mathrm{IC}_{50}$ $105 \mu \mathrm{g} / \mathrm{ml}$. Rutin also showed moderate activity with $\mathrm{IC}_{50}$ of $150 \mu \mathrm{g} / \mathrm{ml}$. Against the ABTS free radical, with $\mathrm{IC}_{50}=$ $90 \mu \mathrm{g} / \mathrm{ml}$, pyrogallol was more potent followed by morin $\left(\mathrm{IC}_{50}=145 \mu \mathrm{g} / \mathrm{ml}\right)$. Ascorbic acid was used as a standard and its $\mathrm{IC}_{50}$ value was $50,62 \mu \mathrm{g} / \mathrm{ml}$ against $\mathrm{DPPH}$ and ABTS free radicals respectively (Table 5 and Fig. 2).

Table 5 Percent ABTS and DPPH radical scavenging potential of pyrogallol, morin and rutin isolated from Bergenia ciliata rhizome using ascorbic acid as standard

\begin{tabular}{|c|c|c|c|c|c|}
\hline Samples & $\begin{array}{l}\text { Concentrations } \\
(\mu \mathrm{g} / \mathrm{mL})\end{array}$ & $\begin{array}{l}\text { DPPH percent } \\
\text { inhibition } \\
\text { (mean } \pm \text { S.E.M) }\end{array}$ & $\begin{array}{l}\text { DPPH IC } C_{50} \\
(\mu \mathrm{g} / \mathrm{mL})\end{array}$ & $\begin{array}{l}\text { ABTS percent } \\
\text { inhibition } \\
\text { (mean } \pm \text { S.E.M) }\end{array}$ & $\begin{array}{l}\text { ABTS IC } C_{50} \\
(\mu \mathrm{g} / \mathrm{mL})\end{array}$ \\
\hline \multirow[t]{5}{*}{ +Pyrogallol } & 1000 & $89.35 \pm 0.92^{\mathrm{ns}}$ & & $87.02 \pm 0.81^{\mathrm{ns}}$ & \\
\hline & 500 & $81.64 \pm 1.33^{\mathrm{ns}}$ & & $77.81 \pm 1.09^{\mathrm{ns}}$ & \\
\hline & 250 & $70.30 \pm 1.05^{\mathrm{ns}}$ & 68 & $66.42 \pm 0.90^{\mathrm{ns}}$ & 85 \\
\hline & 125 & $59.93 \pm 2.18^{\mathrm{ns}}$ & & $53.26 \pm 1.62^{* *}$ & \\
\hline & 62.5 & $48.72 \pm 0.89^{\mathrm{ns}}$ & & $39.60 \pm 1.39^{* * *}$ & \\
\hline \multirow[t]{5}{*}{ Morin } & 1000 & $83.93 \pm 0.72^{* * *}$ & & $80.86 \pm 1.09^{* * *}$ & \\
\hline & 500 & $72.72 \pm 1.56^{* *}$ & & $70.67 \pm 1.02^{* * *}$ & \\
\hline & 250 & $60.25 \pm 2.28^{* * *}$ & 105 & $58.04 \pm 2.44^{* * *}$ & 145 \\
\hline & 125 & $48.72 \pm 1.11^{\mathrm{ns}}$ & & $44.15 \pm 0.56^{* * *}$ & \\
\hline & 62.5 & $40.85 \pm 0.94^{*}$ & & $30.50 \pm 1.43^{* * *}$ & \\
\hline \multirow[t]{5}{*}{ Rutin } & 1000 & $80.90 \pm 1.27^{* * *}$ & & $78.33 \pm 0.63^{* * *}$ & \\
\hline & 500 & $68.43 \pm 1.40^{* * *}$ & & $69.05 \pm 0.64^{* * *}$ & \\
\hline & 250 & $57.47 \pm 0.93^{* * *}$ & 150 & $57.56 \pm 1.42^{* * *}$ & 183 \\
\hline & 125 & $46.63 \pm 1.17^{* * *}$ & & $44.30 \pm 0.79 * * *$ & \\
\hline & 62.5 & $35.38 \pm 2.28^{* * *}$ & & $29.75 \pm 2.18^{* * *}$ & \\
\hline \multirow[t]{5}{*}{ Ascorbic acid } & 1000 & $92.67 \pm 0.73$ & & $89.94 \pm 0.86$ & \\
\hline & 500 & $80.45 \pm 0.96$ & & $80.29 \pm 0.79$ & \\
\hline & 250 & $71.34 \pm 2.16$ & 50 & $68.93 \pm 0.45$ & 62 \\
\hline & 125 & $62.90 \pm 0.85$ & & $58.90 \pm 0.48$ & \\
\hline & 62.5 & $53.78 \pm 0.76$ & & $50.88 \pm 0.32$ & \\
\hline
\end{tabular}


Table 6 Percent AChE and BChE inhibition potential of pyrogallol, morin and rutin isolated from Bergenia ciliata rhizome

\begin{tabular}{|c|c|c|c|c|c|}
\hline Samples & $\begin{array}{l}\text { Concentrations } \\
(\mu \mathrm{g} / \mathrm{mL})\end{array}$ & $\begin{array}{l}\text { AChE percent } \\
\text { inhibition } \\
\text { (mean } \pm \text { S.E.M) }\end{array}$ & $\begin{array}{l}\text { AChE IC } 50 \\
(\mu \mathrm{g} / \mathrm{mL})\end{array}$ & $\begin{array}{l}\text { BChE percent } \\
\text { inhibition } \\
\text { (mean } \pm \text { S.E.M) }\end{array}$ & $\begin{array}{l}\mathrm{BChE} \mathrm{IC}_{50} \\
(\mu \mathrm{g} / \mathrm{mL})\end{array}$ \\
\hline \multirow[t]{4}{*}{ Pyrogallol } & 1000 & $94.35 \pm 0.72^{\mathrm{ns}}$ & & $92.02 \pm 1.89^{\mathrm{ns}}$ & \\
\hline & 500 & $87.40 \pm 1.51^{\mathrm{ns}}$ & & $80.35 \pm 0.30 *$ & \\
\hline & 250 & $80.12 \pm 0.62^{n s}$ & 28 & $71.18 \pm 1.38^{\mathrm{ns}}$ & 70 \\
\hline & 125 & $66.24 \pm 2.14^{\mathrm{ns}}$ & & $58.28 \pm 0.93^{\mathrm{ns}}$ & \\
\hline \multirow[t]{4}{*}{ Morin } & 1000 & $85.51 \pm 3.19^{* * *}$ & & $80.46 \pm 0.76^{* * *}$ & \\
\hline & 500 & $77.23 \pm 0.91^{* * *}$ & & $68.44 \pm 2.22^{* * *}$ & \\
\hline & 250 & $68.82 \pm 0.80 * * *$ & 64 & $60.51 \pm 0.50^{* * *}$ & 116 \\
\hline & 125 & $56.33 \pm 1.45 * * *$ & & $51.13 \pm 0.56^{* * *}$ & \\
\hline \multirow[t]{4}{*}{ Rutin } & 1000 & $75.11 \pm 1.41^{* * *}$ & & $72.05 \pm 0.86^{* * *}$ & \\
\hline & 500 & $66.72 \pm 0.62^{* * *}$ & & $62.47 \pm 1.72^{* * *}$ & \\
\hline & 250 & $60.20 \pm 2.35^{* * *}$ & 118 & $56.68 \pm 0.70^{* * *}$ & 172 \\
\hline & 125 & $48.09 \pm 0.64^{* * *}$ & & $45.00 \pm 3.79^{* * *}$ & \\
\hline \multirow[t]{4}{*}{ Galanthamine } & 1000 & $97.24 \pm 0.74$ & & $92.26 \pm 0.92$ & \\
\hline & 500 & $90.43 \pm 0.50$ & & $86.51 \pm 0.77$ & \\
\hline & 250 & $79.00 \pm 0.65$ & 24 & $71.80 \pm 0.48$ & 54 \\
\hline & 125 & $66.07 \pm 1.46$ & & $62.43 \pm 0.39$ & \\
\hline
\end{tabular}

Galanthamine was used as a positive control. Data is represented as (mean \pm S.E.M) $n=3$. Values significantly different as compared to positive control, *: $P<0.05$, **: $P<0.01,{ }^{* * *}: P<0.001$, ns: $P>0.05$

According to literature, the number and position of hydroxyl $(-\mathrm{OH})$ and methoxy $\left(-\mathrm{OCH}_{3}\right)$ groups in the phenolic acid plays an important role in the scavenging of free radicals [26].

\section{$\mathrm{AChE}$ and $\mathrm{BChE}$ inhibition potential of isolated compounds}

The isolated compounds rutin, morin and pyrogallol inhibited AChE and BChE activities when treated with compound solutions in range of 1000 to $62.5 \mu \mathrm{g} / \mathrm{ml}$. Against $\mathrm{AChE}$, the percent inhibition potential was higher for pyrogallol with $\mathrm{IC}_{50}$ value of $28 \mu \mathrm{g} / \mathrm{ml}$ followed by morin with $\mathrm{IC}_{50} 64 \mu \mathrm{g} / \mathrm{ml}$ while for rutin the $\mathrm{IC}_{50}$ was $118 \mu \mathrm{g} / \mathrm{ml}$. Against the $\mathrm{BChE}$ the $\mathrm{IC}_{50}$ of the isolated compounds; pyrogallol, morin and rutin were 70,116 and $172 \mu \mathrm{g} / \mathrm{ml}$ respectively (Table 6). Galanthamine was used as a standard and its $\mathrm{IC}_{50}$ value was $24,54 \mu \mathrm{g} / \mathrm{ml}$ against $\mathrm{AChE}$ and $\mathrm{BChE}$ respectively.

\section{Conclusion}

In the present study three bioactive compounds; pyrogallol, morin and rutin were successfully isolated in pure form for the first time from Bergenia ciliata. The identification and quantification of these compounds was carried out using reverse phase HPLC, NMR and FTIR techniques. The isolated compounds showed potent antioxidant activities against DPPH and ABTS free radicals. The crude extract and subfractions were also tested for their antioxidant and enzyme inhibitory potentials. The total phenolic and flavonoid contents were also determined. From the results it was concluded that this plant could be used in the form of its extract or as such for the treatment of oxidative stress and neurological disorders. Further studies are needed to evaluate the plant for other medicinal properties as well.

\section{Supplementary information}

Supplementary information accompanies this paper at https://doi.org/10. 1186/s12906-019-2679-1.

Additional file 1: Figure S1. Representative HPLC-UV chromatograms of the standard compounds at $320 \mathrm{~nm}$. Figure S2. HPLC chromatogram of crude extract of B. ciliata rhizome. Figure S3. Chromatogram of ethyl acetate fraction of B. ciliata rhizome. Figure S4. Structures of phenolic compounds identified through using HPLC-UV analysis in crude extract and ethyl acetate fraction of Bergenia ciliata rhizome. Figure S5. Chemical structure of pyrogallol isolated from Bergenia ciliata rhizome. Figure S6. HPLC Chromatogram of the isolated pyrogallol. Figure S7. FTIR spectra of the isolated compound pyrogallol. Figure S8. $\mathrm{H}^{1}$-NMR spectra of the isolated compound pyrogallol. Figure S9. Chemical structure of rutin isolated from Bergenia ciliata rhizome. Figure S10. HPLC Chromatogram of the isolated rutin. Figure S11. FTIR Spectra of the isolated compound rutin. Figure S12. $H^{1}$-NMR Spectra of the isolated compound rutin. Figure S13. Structure of morin isolated from Bergenia ciliata rhizome. Figure S14. HPLC Chromatogram of the isolated morin. Figure S15. FTIR Spectra of the isolated compound morin. Figure S16. $H^{1}$-NMR Spectra of the isolated compound morin 


\section{Abbreviations}

ABTS: 2,2'-Azino-Bis-3 Ethylbenzothiazoline-6-Sulfonic Acid;

AChE: Acetylcholine esterase; B. ciliata: Bergenia ciliata; BChE: Butyryl choline esterase; DPPH: 2,2-Diphenyle-1 picrylhydrazyle; DTNB: 5,5-dithio-bisnitrobenzoic acid; HPLC: High performance liquid chromatography

\section{Acknowledgements}

Not applicable.

\section{Authors' contributions}

HB did the experiment, RZ help in wring the paper, AS helped in enzyme activity while MZ conceived the idea, did literature survey and supervised the work. All authors read and approved the final manuscript.

\section{Funding}

This research work was funded by Higher Education Commission of Pakistan (Project No: 20-2515/R\&D/HEC). The funding body only provided financial support but has no role in the study design, performance, data collection and analysis, decision to publish, or preparation/writing of the manuscript.

\section{Availability of data and materials}

The datasets used and/or analysed during the current study available from the corresponding author on reasonable request.

\section{Ethics approval and consent to participate}

Not applicable.

\section{Consent for publication}

Not applicable

\section{Competing interests}

The authors declare that they have no competing interests.

\section{Author details}

'Department of Chemistry, University of Malakand, Chakdara, Dir Lower, KPK 18800, Pakistan. ${ }^{2}$ Department of Pharmacy, Sarhad University of Science and Information Technology, Peshawar, Pakistan. ${ }^{3}$ Department of Pharmacy, University of Malakand, Chakdara, Dir Lower, KPK 18800, Pakistan.

Received: 5 June 2018 Accepted: 9 September 2019

Published online: 06 November 2019

\section{References}

1. Ekor M. The growing use of herbal medicines issues relating to adverse reactions and challenges in monitoring safety. Front Pharmacol. 2014;4:1-10.

2. Demiray S, Pintado ME, Castro PML. Evaluation of phenolic profiles and antioxidant activities of Turkish medicinal plant Tiliaargentea, Crataegifolium leaves and Polygonumbistorta roots. World Acad Sci Eng Technol. 2009;54:312-7.

3. Khoddami A, Wilkes MA, Thomas RH. Techniques for analysis of plant phenolic compounds. Molecules. 2013;18:2328-75.

4. Khasawneh M, Elwy HM, Fawzi NM, Hamza AA, Chevidenkandy AR, Hassan AH Antioxidant activity and lipoxygenase inhibitory effect of Carallumaarabica and related polyphenolic constituents. Amer J Plant. 2014;5:1623-31.

5. Hamid A, Aiyelaagbe OO, Usman LA, Ameen OM, Lawal A. Antioxidants its medicinal and pharmacological applications. Afr J Pure Appl Chem. 2010:4(8):142-51.

6. Lone AA, Ganai SA, Ahanger RA, Bhat HA, Bhat TA, Wani Al. Free radicals and antioxidants: myths facts and mysteries. Afr J Pure Appl Chem. 2013:7(3):91-113.

7. Natalea D, Nardielloa C, Palermoa M, Muscarellab M, Quintoa DC. Development of new analytical method for the determination of polyphenolic compounds in vegetable origin samples by liquid chromatography and pulsed amperometric detection at a glassy carbon electrode. J Chrom A. 2015;1420:66-73.

8. Sen S, Chakraborty R, Sridhar C, Reddy YSR, De B. Free radicals, antioxidants, diseases and phytomedicines: current status and future prospect. Int $J$ Pharm Sci Rev Res. 2010;3:91-100

9. Ahmad S, Ullah F, Sadiq A, Ayaz M, Imran M, Ali I, et al. Rumex chemical composition, antioxidant and anticholinesterase potentials of essential oil of hastatus D. Don collected from the north west of Pakistan. BMC Complement Altern Med. 2016;16(1):1.
10. Suryanti V, Marliyana SD, Putri HE. Effect of germination on antioxidant activity, total phenolics, $\beta$-carotene, ascorbic acid and a-tocopherol contents of lead tree sprouts (Leucaenaleucocephala (Imk.) de Wit). Int Food Res J. 2016:23(1):167-72.

11. Ruby K, Chauhan R, Sharma S, Dwivedi J. Polypharmacological activities of Bergenia species. Int J Pharm Sci Rev. 2012;15:10-110.

12. Venkatadri R, Guha G, Rangasamy AK. Anti-neoplasticactivity of Bergenia ciliata rhizome. J Pharm Res. 2011:4:443-5.

13. Haq IU, Mirza B, Park EJ, Burns BE, Marler LE, Kondratyuk TP, et al. Preliminary evaluation of cancer chemo preventive and cytotoxic potential of naturally growing ethanobotanically selected plants from Pakistan. Pharm Biol. 2013;51:316-28

14. Bibi Y, Nisa S, Chaudhary MF, Zia M. Antibacterial activity of some selected medicinal plants of Pakistan. BMC Complement Altern Med. 2011;11:52.

15. Meda A, Lamien CE, Romito M, Millogo J, Nacoulma OG. Determination of the total phenolic, flavonoid and proline contents in Burkina Fasan honey, as well as their radical scavenging activity. Food Chem. 2005;91(3):571-7.

16. Park HH, Lee S, Son HY, Park SB, Kim MS, Choi EJ, et al. Flavonoids inhibit histamine release and expression of pro-inflammatory cytokines in mast cells. Arch Pharm Res. 2008;31(10):1303-11.

17. Brand W, Williams M, Cuvelier C. Use of a free radical method to evaluate antioxidant activity. Food Sci Technol. 1995:28:25-30.

18. Re R, Pellegrini N, Proteggente A, Pannala A, Yang M, Rice-Eas C. Antioxidant activity applying an improved ABTS radical cation decolorization assay. Free Radic Biol Med. 1999;26(9):1231-7.

19. Zeb A. A reversed phase HPLC-DAD method for the determination of phenolic compounds in plant leaves. Anal Methods. 2015;7:7753-7.

20. Fischer UA, Carle R, Kammerer DR. Identification and quantification of phenolic compounds from pomegranate (Punica granatum L.) peel, mesocarp, aril and differently produced juices by HPLC-DAD-ESI/MS. Food Chem. 2011;27(2):807-21.

21. Santos J, Oliveira MBPP, Ibáñez E, Herrero M. Phenolic profile evolution of different ready-to-eat baby-leaf vegetables during storage. J Chromat A. 2014:1327:118-31.

22. Uddin G, Rauf A, Arfan M, Ali M, Qaisar M, Sadiq M, et al. Preliminary phytochemical screening and antioxidant activity of Bergenia ciliata. Middle-East J Sci Res. 2012;11(8):1140-2

23. Kamal Z, Ullah F, Ayaz M, Sadiq A, Ahmad S, Zeb A, et al. Anticholinesterase and antioxidant investigations of crude extracts, subsequent fractions, saponins and flavonoids of a triplex laciniata L: potential effectiveness in Alzheimer's and other neurological disorders. Biol Res. 2015;48(1):21.

24. Shan-lin I, bao-lu Z, dongyun OS, wen-Juan X. Auto-oxidation mechanism of pyrogallol and its free radical effects studied by mean $S$ of ESR, UV and NM R. Chem Res Chin Univ. 1999;15(2):146-51.

25. Selvaraj $K$, Chowdhury $R$, Bhattacharjee $C$. Isolation and structural elucidation of flavonoids from aquatic fern azollamicrophylla and evaluation of free radical scavenging activity. Int J Pharm Sci. 2013:5(3):743-9.

26. Yang JY, Lee HS. Evaluation of antioxidant and antibacterial activities of morin isolated from mulberry fruits (morus Alba I.). J Korean Soc Appl Biol Chem. 2012;55:485-9.

\section{Publisher's Note}

Springer Nature remains neutral with regard to jurisdictional claims in published maps and institutional affiliations.

Ready to submit your research? Choose BMC and benefit from

- fast, convenient online submission

- thorough peer review by experienced researchers in your field

- rapid publication on acceptance

- support for research data, including large and complex data types

- gold Open Access which fosters wider collaboration and increased citations

- maximum visibility for your research: over $100 \mathrm{M}$ website views per year

At BMC, research is always in progress.

Learn more biomedcentral.com/submissions 